Vida Pust Škrgulja

Ivanić Grad

\title{
ANTIKA KOT LIKOVNA INSPIRACIJA
}

Tema tega razmišljanja, ki se je razvijala in oblikovala postopno, predvsem $\mathrm{v}$ zadnjih nekaj letih pripravljanja programov za pouk latinščne in likovne umetnosti na gimnaziji v hrvaškem Ivanić Gradu, je zrasla iz želje, da bi se mlademu človeku na zgoščen, a vendar dovolj pregleden in jasen način približalo bogastvo sveta antičnega človeka, kakor se kaže skozi stoletja razvoja evropske in delno tudi zunajevropske likovne umetnosti. Zato naj ne zamerijo tisti, ki so prepričani, da tema zahteva zgolj znanstveno obravnavo.

Menim, da se mora srednješolec najprej seznaniti $\mathrm{z}$ vsakim predmetom kot celoto, da bi ga lahko vzljubil, se nato odločil za poglabljanje v času študija in se morda usposobil za kasnejše znanstveno raziskovanje. Za uspeh pri takšnem delu pa je poleg znanja in sposobnosti kritične presoje potrebna tudi ljubezen do predmeta. Ta pa se najpogosteje poraja prav $v$ mladih srcih.

Namen tega besedila je predvsem prikazati likovno umetnost kot važen segment antične civilizacije, kot dopolnilo umetnosti besede, obenem pa poudariti vlogo, ki jo je in jo še vedno ima klasična umetnost pri oblikovanju profila evropske civilizacije $v$ celoti.

Evropska likovna umetnost skozi stoletja svoje zgodovine in tudi danes nenehno omahuje na razpotju dveh svetov. Ena pot vodi iz temnih obrisov pradavnine, iz časov, ko je duh paleolitskih umetnikov - lovcev na kamnitih stenah podzemnih votlin oblikoval prve sledove miselnih vzorcev ledenodobnega človeka. Neustavljivi šarm te divje, neukročene, zdaj barbarsko razkošne, zdaj $\mathrm{v}$ mistično meglico bretonskih močvirij ovite umetnosti predantične Evrope spremljamo na tej poti vse do današnjih dni. $Z$ njo stopamo po travnatih stezah med menhirji, kjer včasih še zaslutimo neslišne korake druidskih svečenikov in zamolkli odmev njihovih spevov. Vodi nas $\mathrm{v}$ irske samostane zgodnjega srednjega veka, kjer se čudovita ornamentika nabožnih rokopisov $\mathrm{v}$ neverjetnih prepletih barv in oblik spogleduje $\mathrm{z}$ okrasi na predmetih za povsem posvetno rabo. Prasvet, ki ga napolnjuje horror vacui, prepoln živalskih teles in skrivnostnih organskih vijug, je vtkan $\mathrm{v}$ civilizacijske okvirje duhovnih razsežnosti človeka, ki ne občuti lepote gozda, pa četudi pozna vsako posamezno drevo, ki raste v njem. Daleč je svetloba Sredozemlja. Demoni pradavnine obvladujejo kamniti svet peklenskih pošasti, ki zlovešče prežijo iz polmraka romanskih cerkva in mistična luč nebeškega Jeruzalema, ki žari skozi živopisne vitraje in odseva na marmornih čipkah v nebo kipečih gotskih katedral, je svetloba hladnega Severa. Tu srečamo Boscheva monstruozna bitja, ki svet vsakdanjosti napolnjujejo $\mathrm{s}$ strahom in tesnobo, $\mathrm{z}$ občutkom, da je greh že življenje samo. Spremljajo jih nočne more in apokaliptične vizije Füsselija in Blakea, Goyine pošasti iz Quinte del Surdo, Escherjevi labirinti duha med logiko in iluzijo, orgiastični kaos Pollockovih platen ... 
$\mathrm{Na}$ drugi strani stoji racionalni, uravnoteženi svet klasične antične umetnosti, ki je zrasel iz ideala, izraženega v znani, Periklu pripisani misli, da Grki ljubijo lepoto $v$ njeni preprostosti in enostavnosti.

Kaj odlikuje antično misel in ji daje tako posebno, vzvišeno mesto stalne reference $\mathrm{v}$ stoletjih razvoja likovne forme vse do današnjih dni? Kaj daje klasiki njeno klasičnost? So to tisti, v sozvočje mer in proporcev vpeti čvrsti, a vendar nekako nežni obrisi grških svetišč, kristalno jasen zvok, ki kot odmev božanskih sfer še danes odzvanja med ruševinami antičnih gledališč, plemenita, zadržana tragika reliefa na nagrobniku lepe Hegesó? Najbrž vse to skupaj in vsako posebej. Klasična "symmetria", o kateri govori Vitruvijeva Arhitektura, predstavlja v svojem bistvu sofisticiran modularni sistem stavbarstva, $v$ katerem je mera osnovnega modula poljubna spremenljivka, ki pa zahteva precizna izračunavanja vseh ostalih stavbnih mer in proporcev, da bi se uresničila harmonija odnosov med posameznimi stavbnimi deli in celoto, ki ji pripadajo. Toda tudi osnova za Vitruvijevo sintezo leži v grški klasiki 5. stoletja. Polikletov kanon proporcev postavlja za osnovo likovnega izraza skladno oblikovano človeško telo in proporcionalne odnose med posameznimi deli tega telesa in celoto ter $v$ svetu antropomorfnih bogov tako čudovito oživlja idejo božanskega reda, vraslo $v$ lepoto minljivosti snovnega sveta. Tako razumeta umetnost tudi veliki Fidija in gracilni Praksiteles. Prav takšno, antropomorfno videnje umetnostnih pravil pa je vodilo tudi arhitekte, ko so oblikovali odnose med premerom baze in višino vitkih stebrov, določali širino interkolumnijev in debelino arhitravov, razmišljali o nagibu trikotnih timpanov in s pretanjenim občutkom za lepoto in harmonijo vnašali drobne optične popravke, ki so čistim geometričnim oblikam arhitekture vdihnili neko organsko napetost in vzbudili občutek povezanosti in rasti.

Umetnost, ki tako idealno povezuje človeško in božansko, duhovno in snovno, je verjetno lahko zrasla samo $v$ svetu svobode duha. $V$ svetu svobode, ki postane svoboda takrat, ko človek zna in si tudi upa prevzeti breme odgovornosti, ko zna in zmore najti pravo mero besedi in zvoku, barvi in obliki. Ko človeška roka iz bleščečega marmorja izkleše vitek steber in mu najde pravo mesto $v$ ritmu kolonade, ki s plemenitostjo oblike dopolni lepoto narave same. Klasika naravo dopolnjuje, noče si je podrediti in je zasenčiti. In ta čudoviti občutek za pravo mero, ki dejansko vzpostavlja tudi harmoničen odnos med človekom, Bogom-Demiurgom in naravo, je navdihnil tudi vsa kasnejša obdobja umetnosti, ki so se napajala ob klasiki. Toda tako idealnega ravnotežja skorajda nikoli več ni bilo mogoče ponoviti. Na poantično evropsko umetnost in še celo na poklasično antično umetnost je vse prepogosto vplivala ideologija, ki je že $\mathrm{v}$ svojem najglobljem bistvu izključevala harmonijo, skladen odnos med deli in celoto, $\mathrm{v}$ kateri prav noben delček ni oropan svojega pomena, kjer je tudi najmanjša vitica $v$ ornamentu nepogrešljiva, saj njeno mesto ni določeno slučajno. Kasnejša stoletja so stoletja priznavanja avtoritet, ki se izrazito dvigajo nad celoto in se od nje zavestno, hoteno razlikujejo $z$ bolj ali manj očitno tendenco politične, duhovne, materialne ali še kakšne nadvlade, ki avtomatično vključuje demokraciji in harmoniji povsem tuje vsiljevanje idejnih in formalnih obrazcev. Za rezultat, ki ga $v$ našem primeru poskušamo spremljati v svetu likovnih form, pa ni važno, ali se umetnost podreja ideji Cerkve, ideji absolutistične monarhije, meščanske ali komunistične revolucije, funkcionalizma in tehnokracije, nacizma ali anarholiberalizma. Skladnost je porušena. Klasike ni več. In paradoksalno - klasika 
izgine tudi iz najčistejše klasicistične forme, če je njena idejna zasnova klasiki tuja. Zato verjetno smemo reči, da klasika živi v Michelangelovem Davidu in sužnju z nagrobnika Julija II., v Canovinem Napoleonu pa je le še posnetek posnetka, podobna mehaničnemu slavcu iz pravljice o kitajskem cesarju.

Najbrž ne bomo daleč od resnice, če $v$ tem kontekstu zaključimo, da bi rušenje, brisanje "klasičnih" antičnih prvin, ki jih vsebuje evropska umetnost, uničilo prepoznavno identiteto te umetnosti. Ni važen konkreten odnos Evrope do antike v posameznih obdobjih njene zgodovine, ki se je spreminjal od odobravanja, oponašanja in poveličevanja preko kritike in negacije do zavestnega prezira in omalovaževanja. Pomembno je, da je ta odnos obstajal skozi vsa dolga stoletja in da brez njega in torej brez antike Evropa ne bi bila odigrala vloge, ki jo še danes igra tudi na svetovnem umetnostnem prizorišču.

$\mathrm{V}$ naslednjem kratkem pregledu poskusimo s pomočjo slikovnega gradiva osvetliti nekatere segmente evropske likovne umetnosti, $\mathrm{v}$ katerih prepoznavamo odseve antike zlasti $\mathrm{v}$ oblikah arhitekture, kiparstva in slikarstva ter $\mathrm{v}$ bogastvu ikonografskih motivov evropske umetnosti.

V očeh zgodovinarja je antika obdobje, razpeto med časi, ki jih opevajo homerski epi, in zgodnjim srednjim vekom. Obdobje, po trajanju primerljivo s celotno poantično zgodovino do današnjih dni. Tudi likovna umetnost antičnega obdobja je potrebovala stoletja, da se je lahko razvila do stopnje, ki jo označujemo s terminom "klasična antika" in ki dejansko ustreza samo največjim umetninam 5 . in 4. stoletja pred Kristusom. Predklasično obdobje je nekako obdobje prebujanja, medtem ko že helenizem, zlasti pa Rim, privedeta do prvih podoživitev klasičnih grških umetnostnih snovanj.

Ravnotežje klasike $v$ helenističnem obdobju ruši pretirana dinamika forme, pretirano izražanje čustev, moči, šibkosti - skratka ljubezen do skrajnosti, pri čemer poudarjanje individualnosti, enega, zapostavlja sklad tega enega s celoto. Dominacija je zamenjala demokracijo, kontrast je porušil harmonijo.

Rimska umetnost je $\mathrm{v}$ arhitektonskem in urbanističnem snovanju stopila za korak naprej od klasične Grčije. V arhitekturi, kjer je funkcionalnost vsaj enakovredna lepoti oblike, je praktični rimski duh $\mathrm{z}$ novimi konstrukcijskimi in formalnimi prvinami obogatil estetsko dovršene stvaritve klasike in dosegel zavidljivo sintezo antičnih stavbeniških snovanj, ki v poantični likovni tradiciji predstavljajo temelj za vse klasicizmu naklonjene smeri evropskega stavbarstva.

Drugače je bilo v upodabljajoči umetnosti. Rimska samobitnost, poudarjena resnicoljubnost, težnja za individualnim in prepoznavnim je ob naslonitvi na grško tradicijo razvila rimski republikanski portret, $\mathrm{ki}$ ob reliefih $\mathrm{z}$ upodobitvami zgodovinskih prizorov zavzema posebno mesto $\mathrm{v}$ pregledu rimske avtonomne umetnosti. Velik del rimskih umetnin je pač nastal pod tolikšnim vplivom Grčije, da jih marsikdaj lahko ocenjujemo predvsem po uspešnosti približevanja grškim vzorom in po formalno-tehnični dovršenosti oblikovanja. Na rimsko obdobje evropske likovne umetnosti torej lahko gledamo na dva načina. Po eni strani kot na podaljšek, dopolnilo grške umetnosti in važno komponento v oblikovanju pojma "klasični temelji evropske umetnosti" $v$ širšem pomenu, obenem pa na prvo "renesanso" $v$ smislu obnove in poustvaritve grške klasike $\mathrm{v}$ novih zgodovinskih in zemljepisnih okvirjih. 
Ko izzveni obdobje pozne antike, ki jo spremlja postopno razkrajanje in preoblikovanje klasičnih formalnih prvin $v$ duhu nove krščanske ideologije, se zahodna Evropa, četudi v krščanski preobleki, spet vrača $\mathrm{k}$ svojim pradavnim koreninam predantične ornamentalnosti. V arhitekturi tega obdobja je antika le še meglen spomin. Spolije antičnih stavb so enakovredne vsakemu grobo obdelanemu kamnu, primitivnemu zidu ali grobo obtesanemu deblu. Toda antika vendar ni umrla. Že pred obdobjem Karla Velikega, znamenito "karolinško renesanso", se pojavljajo oblike, $v$ katerih zaslutimo antičnega duha, pa četudi spremenjenega do stopnje grotesknega. Toda nov čas že nosi nove spremembe.

Zapisi, ki govore o kulturi na dvoru Karla Velikega, kjer je sam vladar predstavljen kot "David" in "Cezar" obenem, katerega krščanska "Akademija" se postavlja s tedanjo intelektualno elito Evrope, med katero se pojavi novi "Flaccus" (Alkuin), "Homer" (Angilbert), "Naso" (Modoen) in "Vergil" (Teodulf), nedvomno govore o pomembni vlogi, ki jo je imela antična tradicija na Karlovem dvoru. To potrjuje tudi ornamentika in arhitektonska zasnova Palatinske kapele $\mathrm{v}$ Aachenu. Toda o času mogoče bolj zgovorno govori vzhodna lopa samostana v Lorschu iz sredine 8. stoletja, na kateri že na prvi pogled prepoznamo zunanjo osnovno obliko rimskega slavoloka, a je vendar ne moremo zamenjati $\mathrm{z}$ antičnim spomenikom. Vsa monumentalnost Rima je izginila. Nadomestila jo je ploskovita, površinska dekorativnost, ki je izgubila miselni stik s prevzeto obliko.

Prvi veliki vseevropski stil, ki se očitno naslanja na antične, zlasti na rimske prvine, je romanika. Naslon na rimsko arhitekturo je jasno viden zlasti $v$ osrednji in severni Italiji ter $\mathrm{v}$ deželah močnih italijanskih vplivov $\mathrm{v}$ umetnosti. $\mathrm{Na}$ severu in zahodu Evrope je ta povezanost manjša, toda tudi ta arhitektura, četudi regionalno tako specifično prepoznavna, je ohranila polkrožni lok kot glavno konstruktivno in dekorativno obeležje romanskega stila, antiki pa je blizu tudi arhitektonska čistost, jasnost, preglednost in preciznost gradnje, ki dosega strogi, monumentalni rimski "opus quadratum". Tudi spomin na razkošje antičnega atrija in peristila se je ohranil v sicer strogo zarisanih linijah samostanskih križnih hodnikov, kjer se skladni ritem kolonad združuje $\mathrm{z}$ romansko ikonografijo kapitelov in $\mathrm{z}$ vodnjakom na križišču vrtnih stezic, ki menihu $\mathrm{v}$ kontemplaciji pričara "hortus conclusus" v jeziku sholastične simbolike.

Gotika kot naslednje veliko slogovno obdobje, ki v mistični lepoti marmornih okrasij, skozi katera proseva obarvana svetloba slikanih oken, kipi ob vitkih služnikih $v$ drzne višine, je na prvi pogled daleč od antike in telesnosti Sredozemlja. Toda v dveh stoletjih razvoja se je tudi $v$ ta, tako tipično neitalijanski stil po prstih prikradlo čustvo. Nežnost, milina in sočutje si ob telesni lepoti počasi utirajo pot ob grobem germanskem naturalizmu. Še podoba Boga, ki je v romaniki veliki gospodar vesolja in neizprosni sodnik strašnega dne poslednje sodbe, se izpreminja v podobo nesrečnega, izmučenega, od vseh pozabljenega in osamljenega človeka. Toda človek, ki vse bolj zanesljivo vstopa $v$ svet poznosrednjeveške umetnosti, ter narava, ki - navdihnjena ob himnah Frančiška Ašiškega - zeleni in se razcveta na kapitelih in listnatih maskah gotskih katedral, že napovedujeta rojstvo novega časa.

Renesansa v umetnosti ponovno ustoliči duha antike. Narava je delo božanskih rok in božanskega uma in tudi človek, krona in merilo stvarstva, je ustvarjen kot plod božanskega načrta. Neoplatonisti govore o človeku, ki je po naravi dober in kot 
utelešenje božanske ideje nujno lep. Opora za racionalno idealizacijo je antična umetnost. Nič ni slučajno, nič ni nastalo brez razloga. Ritem, skladnost in harmonija umetnosti po meri človeka se $v$ marsičem opirajo na antiko. Toda to vendar ni antika. A kljub temu - kaj bi sploh bila renesansa brez antike? $\mathrm{Bi} v$ njej prevladali brezkompromisni pohlep in oblastiželjnost tekmovalnega duha hrabrih, a neizobraženih kondotierov, pretkanost in grabežljivost trgovcev in cehovskih mojstrov? $\mathrm{Na}$ čem bi svojo veličino in kulturni profil gradili Sforze, Medicejci, Malateste, ko bi prav v antiki ne našli tistega pozitivnega nasprotnega pola, protiuteži, ki je pomagala, da se je podoba mecenov, ljubiteljev in zaščitnikov umetnosti dvignila nad podobo okrutnih in sebičnih tiranov ter jo dodobra potisnila $\mathrm{v}$ senco?

Renesančna arhitektura po eni strani vzpostavlja red, preglednost, racionalnost, naklonjena je gradnji centralnih stavb, iz središča katerih lahko človek doživi sebe kot središče stvarstva, arhitekturo pa kot dovršeno podobo kozmosa. Ob čistih, preprostih oblikah zgodnje renesanse se proti koncu 15., zlasti pa v 16. stoletju vse pogosteje pojavljajo tudi čiste antične oblike arhitektonskih elementov. Obdobje, naklonjeno znanosti, raziskovanju in odkrivanju zakonitosti $\mathrm{v}$ naravi, človeku in njegovih delih, ki je upodabljajoči umetnosti podarilo tektonsko kompozicijo in odkritje perspektive, je v Arhitekturi ponovno odkrilo tudi Vitruvija. Renesansa obnovi antični kanon proporcev, klasični kontrapost in tisti, za klasiko tako tipični spoj realizma in estetske idealizacije, ki ga opazimo tako v Miloški Veneri kot v. Rafaelovi Madoni. Toda Rafaelova klasičnost ne pripada antiki in tako zelo klasicistična Palladijeva Villa Rotonda ne moe biti antična arhitektura. In vendar - si lahko zamislimo stil Rafaela in Palladija, ko bi humanistična zavest renesančnega človeka ne odstrla težke zavese pretekle zgodovine in sprejela antike kot ponovno rojene, neuničljive in trajne inspiracije evropske umetnosti?

Podobno kot grška klasika pa je tudi visoka renesansa formalno popolnost in idealno usklajenost oblike in vsebine sčasoma občutila kot obremenitev. Sprememba v smislu boljše, popolnejše zasnove ni bila možna. Mogoč je bil le premik v drugo smer, rušenje popolnosti, da bi dosegli neko novo kvaliteto. Maniristična iskanja v umetnosti 16. stoletja so zato, kljub neizpodbitni vrednosti in kvaliteti umetnin, ki so jih ustvarile roke Tintoretta, El Greca, Dürerja, nedvomno dokaz za nekakšen umetnostni "interregnum", inspirativno, kreativno bogato obdobje, ki pa prav zaradi po eni strani slepega ponavljanja že videnega, po drugi pa izjemne svobode $v$ iskanju novega omogoča kristalizacijo najboljšega, ki bo rodilo nekaj novega. To novo je $\mathrm{v}$ novih zgodovinskih relacijah Evrope ustvarilo barok.

Podobno kot $\mathrm{v}$ umetnosti helenizma ter $\mathrm{v}$ razcvetu rimske umetnosti prvega velikega cesarskega obdobja najpogosteje ne moremo več govoriti o klasiki, vsekakor pa še vedno o vrhovih umetniške ustvarjalnosti antike, tako tudi barok kot zadnji veliki vseevropski umetnostni slog ne zraste iz negacije, temveč iz preoblikovanja renesančnega doživetja antike. Seveda ob paraleli helenistične in baročne umetnosti ne gre toliko za neposreden vpliv prve na drugo, pa četudi je patos, s katerim je prežeta helenistična Laokoonova skupina, enak patosu Berninijeve sv. Terezije. Za razumevanje stila je morda bolj zanimivo postaviti paralelo med zgodovinskimi razmerami, $v$ katerih sta nastali obe skulpturi in ki so ustvarili podobno ozračje za umetniško ustvarjanje. Relativna izguba svobode izražanja misli, ki pomeni tudi izgubo smisla deklarativnega priseganja na ideale, se v umetnosti nadomešča s težnjo 
po dramatičnosti in patetiki, po prikazovanju skrajnosti, s slikovito rabo kontrastov in silovito dinamiko kompozicije. Barok, umetnostni izraz protireformacije, je spočet $\mathrm{v}$ Rimu. Ena od bistvenih idej pri oblikovanju baročnega sloga v likovni umetnosti je bila tudi želja, da bi papeški Rim, ki ga je renesansa obogatila z deli Bramanteja, Rafaela, Michelangela ter množice morda manj znanih umetnikov, v 17. stoletju po razkošju in obilju umetnin zasenčil nekdanji antični cesarski Rim in tudi s pomočjo vizualne predstave dosegel absolutni primat $v$ krščanskem svetu. In če v rimskem baroku lahko kje prepoznamo antiko, je to nedvomno $v$ profani ikonografiji, prepolni klasičnih mitoloških prizorov, $\mathrm{v}$ oblikah klasičnih stebrnih redov, $\mathrm{v}$ relativnem spoštovanju klasičnega kanona proporcev anatomsko pravilnih človeških teles, toda neverjetna dinamika slikovitih oblik in barv, sence in svetlobe, resnice in iluzije je kot divja orkestracija preglasila klasično osnovo motiva. Le redki umetniki in le $v$ nekaterih delih ohranjajo občutek za uravnoteženost ideje - vsebine in oblike, toda v duhu, ki je primerljiv s helenizmom, ne pa s klasiko.

Drugače je v deželah, kjer rimski barok ni bil nikoli v celoti občuten in sprejet. To velja zlasti za Francijo, kjer mnoga Vitruvijeva teoretična pravila spoštujejo še v 18. stoletju. Dežela kartezijanskega racionalizma, pronicljivega galskega duha in občutka za pravo mero je bila očitno bolj naklonjena klasicističnim projektom kot pa neobvladljivim, difuznim prvinam italijanskega baroka. Zato ni čudno, da Pariz kot možnega graditelja Louvra, kraljeve rezidence, odkloni velikega Berninija, nespornega kralja rimske ahitekture in skulpture. Francoskemu racionalizmu in klasicizmu ja naslonitev na arhitektonske forme klasične Grčije le potrditev odličnosti lastnega obdobja, pri čemer je bila izbira klasičnih slogovnih oblik verjetno razumljiva že sama po sebi. Nebrzdano moč in zagon italijanskega baroka je obvladala strogost elegantnih in dostojanstvenih linij, ne da bi se izgubila mogočnost in suverena prepoznavnost sloga.

Podobne klasicistične tendence opazimo tudi v angleški arhitekturi 17. stoletja, kjer $\mathrm{v}$ stvaritvah Iniga Jonesa in Christopherja Wrena lahko spremljamo pri prvem očitna naslonitev na Palladijev stil poznega 16. stoletja, pri drugem pa zasledimo celo jasen odsev oblik rimske visoke renesanse ter smo tako znova pri $\mathrm{v}$ drugo ali celo $\mathrm{v}$ tretje preoblikovanih antičnih formah.

Toda vrnimo se za trenutek v Francijo in se pomudimo v svetu upodabljajoče umetnosti. Slikar Nicolas Poussin je italijansko slikarstvo spoznal v Rimu, kjer je preživel večji del svojega življenja. Toda njegova, pogosto pri Ovidiju navdihnjena dela ne govore $v$ jeziku rimskega baroka. Izžarevajo pa nek klasičen, skorajda grški mir in občutek za harmonijo ter za povezanost človeka $z$ naravo. Tudi svojevrstni stil slikarja Georgesa de la Toursa, omejen na najnujnejše, tematsko prepoznavne elemente kompozicije, se kljub intenzivnemu chiaro-scuro kontrastu, ki le še poudarja skorajda klasično zadržanost in lepoto preprostih, plemenitih oblik, morda nehote približuje idealu grške umetnosti klasičnega obdobja. Vsaj še enega francoskega umetnika te dobe omenimo. To je Jean Antoine Houdon, katerega skulpture Voltaira in Rousseauja izžarevajo po eni strani klasičen mir antičnih filozofov, po drugi pa neustavljivo spominjajo na rimski republikanski portret, katerega racionalistični potomci ob koncu 18. stoletja že napovedujejo nov čas.

In nov čas je prišel. Kot vse revolucije - $v$ krvavi zarji prevrata, toda poln velikih misli in besed o svobodi, enakosti, bratstvu, o poštenju in demokraciji. In 
kateri pretekli stil $\mathrm{v}$ umetnosti bi bolj ustrezal zanosu prvih uspehov francoske revolucije kot stroga klasična forma antične arhitekture, ki že na zunaj spominja na obdobje prve demokratične misli v evropski zgodovini, kateri motivi bi dajali moralno oporo novi oblasti, ko bi se umetniki ne vrnili $\mathrm{k}$ velikim temam in legendam starega Rima, k zgodbam iz časov, ko so "boni mores" dajali moč državi, ko so na čelu zmagovite rimske vojske stali "dictatores ab aratro", ko je "amor patriae" predstavljal najvišjo obliko človekove ljubezni ter so čast, poštenje in dostojanstvo gradili ugled in moč mlade države med sosednjimi plemeni.

Toda človeška narava je lahko pokvarljiva. Ko je Napoleon občutil vso slast oblasti, so tudi $v$ umetnosti porevolucionarne Francije robati rimski republikanci prepustili svoje mesto prefinjenim, pomehkuženim aristokratom cesarskega, ob helenistični čutnosti oplajajočega se Rima. Klasicistična, ne več klasična; poltena, obenem pa hladna lepota likovno umetnost spet vlečeta proč od bistva vzora, $h$ kateremu deklarativno teži. In četudi slikarstvo in kiparstvo 19. stoletja vẹčkrat poskušata iskreno obuditi spomin na čas stare Grčije in Rima, nam njihova dela prikazujejo svet antike, kot ga vidi oko umetnika 19. stoletja, ki v romantični nostalgiji obdobja prve industrijske revolucije išče "izgubljeni raj" v idealiziranih podobah zdavnaj izginulega sveta.

Drugače je v arhitekturi 19. stoletja, kjer v pravi poplavi psevdozgodovinskih stilov zavzemajo posebno mesto stavbe, ki v novem, meščanskem okolju mladih republikanskih prestolnic predstavljajo simbol nove demokracije, njene pravičnosti, državniške moči in ugleda in ki skoraj izključno prisegajo prav na klasične forme grške arhitekture. In ob Evropi se klasičnih oblik morda še tesneje oklene Amerika in jih doživlja kot najsvetejše simbole mlade demokracije v veliki državi Novega sveta.

Toda časi so se temeljito spremenili. Nosilna armatura Kipa Svobode je delo Gustava Eiffela, briljantnega graditelja metalnih konstrukcij, katerega dela dokončno pomenijo konec historicizmu $\mathrm{v}$ arhitekturi. Na pragu 20. stoletja, ki med odkritji in spoznanji znanosti in tehnike neizogibno poseže tudi $v$ svet likovnih snovanj, ko odkritje in razvoj fotografije in filma neposredno vpliva na rojstvo impresionizma in postimpresionističnih iskanj, se krmilo razvoja začenja obračati vse hitreje in vse bolj daleč proč od klasičnih meril. Le še redki posamezniki med umetniki, ki želijo ostati na površju novih tokov, se včasih še zatečejo $k$ antičnim vzorom. To so ljudje, za katere je, kot za našega Plečnika, stavbarstvo visoka umetnost, "Architectura perennis", ki idejno sporočilnost postavljajo nad golo funkcijo, ki vse bolj prevladuje $v$ arhitektonski miselnosti 20 . stoletja. Zasnovana $v$ duhu moderne dobe, Plečnikova arhitektura vendarle govori $v$ jeziku daljnih potomcev klasične antike in $v$ igri svetlobe in sence med vitkimi kolonadami zaslutimo odsev Berninija, pa odsev helenističnih peristilov in stoe na Agori, zapuščenega foruma Leptis Magnae in dostojanstva Akropole...

Stoletje svetovnih vojn pa je že zdavnaj začelo svoj uničevalni pohod. Umetnost, ki odgovarja na izzive časa, išče izvor svoje izpovednosti $v$ absurdu, $v$ destrukciji, v nadrealnem svetu psiholoških ugank in fantazmagorij, včasih v hladni estetiki in logiki čistih geometrijskih oblik in barvnih ploskev... Funkcionalnost je prevladala nad estetiko in olimpski bogovi so ob koncu železne dobe dokončno zapustili Zemljo. Spomin nanje izzveneva v otožni tesnobi metafizičnega slikarstva Giorgia de Chirica, kjer sta Hektor in Andromaha le še brezimni lutki, izgubljeni v 
minljivem trenutku prostora in časa. Vznemirjene muze čakajo na praznem trgu kot ruševine neke zdavnaj mrtve preteklosti in Emstov "Oedipus Rex" je od kralja Ojdipa ohranil le še ime. Nadrealistični splet simbolov Freudove psihoanalize, prikrite seksualnosti in nasilja, zaprtih $\mathrm{v}$ usodni krog nerešljivih razmerij, krog, $\mathrm{v}$ katerem je svoboda, ki jo simbolizira oddaljeni, v nebo dvigajoči se balon, za protagoniste drame vse bolj nedosegljiva (Argan - PKG - 20. stoletje)... Toda nova figurativnost zadnjih desetletij 20. stoletja spet vzpostavlja dialog s človekom. Svet se spreminja. Bo nova spiritualizacija družbe na prelomu tisočletja $\mathrm{z}$ novim iskanjem harmonije $\mathrm{v}$ človeku, med človekom in naravo, človekom in svetom ter človekom in Bogom znova odkrila izročilo antike? Izročilo, ki zna postaviti meje človekovi avtonomiji, toda meje, ki se šrijo v njegovi notranjosti, ga bogatijo in plemenitijo. Svoboda ni anarhija. Svoboda je možnost izbire, izbira pa postavlja tudi etične kategorije in z njimi odgovornost. In spet se približamo Platonu in neoplatonistom. Tudi v umetnosti. In antika se tudi na pragu 21. stoletja znova pojavlja kot utelešenje večne, četudi neuresničljive želje človeka, da se v minljivosti snovnega približa svetu popolnosti nedosegljive ideje Lepega in Dobrega.

\section{SUMMARY}

The aim of this paper is to present the role of the classical antiquity and its art throughout the centuries, which formed the profile of the European civilisation, as seen from the wiev-point of a secondary school teacher of Latin and History of Art. The text is trying to give a cut through the European art from its early beginning in prehistorical times to some recent works of the 20th century artist, speaking in a way acceptable to a teen-age audience. Its main idea is that the rules of beauty and harmony that the Classical Antiquity had developed some 25 centuries ago, functioned as a continuous reference of the European art not only in the years of praise and glory, but also in the periods of denial and even open resistance.

The Art, travelling through Chaos and Disorder always finds new services of inspiration in classical Order and Harmony, reminding us of the everlasting search of immortal beauty, maybe the missing link in a lost harmony between Creator, Nature an Man. 